\title{
Agrobacterium-mediated Genetic Transformation for Local Cultivars of Potato (Solanum tuberosum L.) Using Marker Genes
}

\author{
Rita Sarah Borna, M. I. Hoque and R. H. Sarker* \\ Plant Breeding and Biotechnology Laboratory, Department of Botany, University of \\ Dhaka, Dhaka 1000, Bangladesh
}

Key words: Potato, In vitro regeneration, Transformation

\begin{abstract}
Genetic transformation using nodal and internodal segments from three economically important potato (Solanum tuberosum L.) varieties namely, Diamant, Cardinal and Granola was conducted using an Agrobacterium tumefaciens strain LBA4404 harbouring binary plasmid pBI12 containing the GUS and nptII genes. Node and internodal segments were used for direct regeneration as well as regeneration with the intervention of callus. Best responses were obtained for direct regeneration of shoots when the explants were cultured on MS supplemented with $4.0 \mathrm{mg} / \mathrm{l} \mathrm{BAP}+1.0 \mathrm{mg} / \mathrm{l} \mathrm{IAA}, 1.5 \mathrm{mg} / \mathrm{l} \mathrm{BAP}+0.5 \mathrm{mg} / \mathrm{lAA}$ and $5.0 \mathrm{mg} / \mathrm{l} \mathrm{BAP}$ $+1.0 \mathrm{mg} / \mathrm{l}$ IAA in Diamant, Cardinal and Granola, respectively. In Diamant spontaneous in vitro microtuberization was obtained from these proliferated shoots. Further culturing of these in vitro grown green microtubers regenerated a large number of shoots on MS containing $4.0 \mathrm{mg} / \mathrm{l} \mathrm{BAP}+1.0 \mathrm{mg} / \mathrm{l} \mathrm{IAA}$. By combining the best treatments, this protocol yielded an average transformation rate of $87 \%$ of treared explants. Stable expression of GUS gene was visualized in the various parts of transformed shoots through histochemical assay. Genomic DNA was isolated from transformed shoots and stable integration of the GUS and nptII genes was confirmed by PCR analysis.
\end{abstract}

\section{Introduction}

Potato (Solanum tuberosum L.) is a tuberous crop plant of the Solanaceae family. It is an agronomically important food crop and widely cultivated all over the world. As a major non-cereal crop, potato is exceeded only by wheat, rice and maize for human consumption. In Bangladesh potato is the third important crop and rapid development of modern technology has made potatoes the second largest crop (by weight) in Bangladesh after rice. In 2007 - 08 per hectare yield of potato in Bangladesh was $16.578 \mathrm{MT}$ which is much greater than that of rice (1.639 MT)

*Author for correspondence. <rhsarker2000@yahoo.co.uk>. 
(BBS 2009). At present $0.87 \%$ of the cultivable lands are used in potato cultivation in Bangladesh. The annual yield is about $6648 \mathrm{MT}$ which is about $7.3 \%$ of the total cultivated food crops. However, the production of potato in Bangladesh is still low (16.57 MT/ha) compared to the average yield in Germany and Netherlands (35 and $43 \mathrm{MT} / \mathrm{ha}$, respectively). In South Korea the yield of potato has been increased from 20.0 to $35.0 \mathrm{MT} / \mathrm{ha}$ (Joung et al. 1993). This kind of dramatic increase of average yield is possible due to the cultivation of improved varieties of potatoes.

Production of potato becomes increasingly important for Bangladesh agriculture. However, the improvement in potato production faces several constraints. The yield is reduced greatly due to the shortage of quality seed potato. Moreover, the production and quality of this crop are not equivalent to global standard due to its cultivation under biotic and abiotic stresses such as diseases, pests and climatic factors. The major constraints of potato production in several countries including Bangladesh are due to incidence of different types of fungal diseases (late blight, early blight, etc.). Late blight caused by Phytophthora infestans is the most damaging disease of potatoes worldwide. This disease affects potato development from emergence to harvest. Genetic resistant to late blight is hard to obtain. As a consequence a large amount of fungicides have been frequently applied leading to pollution of the natural environment.

With the advent of new strains of late blight, pressure to sustain food production and preserve the environment in an alarming proportion. Therefore it is desirable to develop fungus resistant plants through the introduction of foreign fungal resistant genes into them. Conventiontional breeding techniques for the improvement of potato is not applicable in our country, because in this climatic condition it has not been possible to induce flowering. Under these circumstances, genetic transformation may be one of the method of choice to introduce a new character in the gene pool of potato.

Considerable progress has been made on the transformation of potato and a number of transgenes have been designed to improve agronomic and quality traits (Voyda and Belknap 1992, Trujillo et al. 2001). In Bangladesh only a limited number of reports are available on genetic transformation of local cultivars of potato. All preliminary investigations have been conducted through Agrobacterium-mediated genetic transformation (Sarker and Mustafa 2002, Sultana 2005, Sarker et al. 2009). For the present set of experiment Agrobacteriummediated genetic transformation was carried out using two different explants from three local varieties of potato. Apart from these studies in vitro regeneration methods facilitating transformation of these varieties, namely, Diamant, Cardinal and Granola have been also reported here. Following Agrobacterium-mediated genetic transformation expression of GUS reporter gene was detected by 
histochemical assay. Integration of GUS and nptII gene was confirmed by PCR analysis.

\section{Materials and Methods}

Tubers of three varieties of potato (Solanum tuberosum L.), namely Diamant, Cardinal and Granola collected from Bangladesh Agricultural Research Institute (BARI), Joydevpur, Gazipur were used in the present investigation. Freshly developed sprouts were used as the primary explants for the establishment of in vitro cultures. From the in vitro grown shoots, node and internodal segments were used for direct regeneration as well as regeneration with intervention of callus.

The sprouts were first washed three times in distilled water and surface sterilized with $0.1 \% \mathrm{HgCl}_{2}$ for 7 - 8 min inside a laminar flow cabinet. The surface sterilized sprouts were cultured on MS supplemented with $4.0 \mathrm{mg} / 1 \mathrm{BAP}$ and 1.0 $\mathrm{mg} / 1$ IAA to obtain shoots. The desired explants were collected from these shoots. MS with various combinations of IAA, NAA, BAP, Kn, GA3 were used for in vitro regeneration. The $\mathrm{pH}$ of the medium was adjusted to 5.8 before autoclaving. Cultures were maintained in growth room with a photoperiod of $16 \mathrm{hr}$ at $25 \pm 1^{\circ} \mathrm{C}$. For induction of roots, regenerated shoots ( $3-4 \mathrm{~cm}$ long) were excised and transferred to half strength of MS supplemented with different concentrations of IBA.

For genetic transformation, Agrobacterium tumefaciens strain LBA4404 containing the binary plasmid pBI121 was used. This plasmid contains a scoreable reporter gene GUS ( $\beta$-glucuronidase) driven by CaMV35S promoter and NOS terminator and a selectable marker gene npt II fused between NOS promoter and NOS terminator encoding for the enzyme neomycin phosphotransferase conferring kanamycin resistance (Herrera-Estrella et al. 1983).

The preparation of Agrobacterium suspension and transformation experiments were conducted following the procedures described by Sarker et al. (2003). The explants of node and internodal segments collected from 3 - 4 week old in vitro grown shoots were used for transformation. Only the apical three node and internodes were used for this purpose. The explants were prepared with a scalpel while submerged in the Agrobacterium suspension. The prepared explants were kept incubated in the Agrobacterium suspension in a small Petri dish for an additional $30 \mathrm{~min}$, then blotted dry and cocultured for three days in the dark on MS with $4.0 \mathrm{mg} / \mathrm{l} \mathrm{BAP}$ and $1.0 \mathrm{mg} / \mathrm{l} \mathrm{IAA}$. After coculture the explants were washed in Ticarcillin (500 mg/l) to stop the excess growth of Agrobacterium. They were then cultured on the regeneration medium for shoot development and maintained in the growth room. 
Since nptII gene was present in the plasmid putatively transformed shoots were cultured on different concentrations of kanamycin containing MS for selection of transformants. To eliminate the untransformed developing shoots from the cultures the explants were subcultured on fresh regeneration medium initially with $50 \mathrm{mg} / \mathrm{l} \mathrm{kanamycin}$. The selection pressure of kanamycin was gradually increased from $50 \mathrm{mg} / \mathrm{l}$ up to 200 and $150 \mathrm{mg} / \mathrm{l}$ kanamycin was optimum in killing the non-transformed shoots. In the optimum selection medium containing $150 \mathrm{mg} / \mathrm{l}$ kanamycin both albino and green shoots were observed. The survival of green shoots on the optimum selection medium indicated the production of transformed shoots. Transforming ability of the explants as well as stable expression of the GUS gene was monitored by GUS histochemical assay (Jeffereson et al. 1987) by submerging them in the substrate $\mathrm{X}$-gluc (5-bromo, 4-chloro, 3-indolyl $\alpha$-D glucuronide) and incubating them at $37^{\circ} \mathrm{C}$ for $24-48 \mathrm{hr}$ and subsequently bleached with $70 \%$ ethanol before scoring for GUS expression.

Genomic DNA was isolated from the transformed potato shoots and stable integration of GUS and nptII genes were confirmed by PCR analysis.

CTAB method (Doyle and Doyle 1990) was used for DNA isolation. For the detection of the nptII coding sequence, DNA was subjected to PCR using the following primers: forward-5'-TAG CTT CTT GGG TAT CTT TAA ATA-3' and reverse-3'-CCA GTT ACC TTC GGA AAA AGA GTT-5'. For the GUS gene the primers were : forward 5'-CCT GTA GAA ACC CCA ACC CG-3' and reverse 5'TGG CTG TGA CGC ACA GTT CA-3'. All primers were used at a concentration of $100 \mathrm{pmol} / \mu \mathrm{l}$. The DNA isolated from transgenic tobacco was used as the positive control. Master mixture was prepared by mixing all of the PCR components e.g. 10x buffer, dNTPs, $\mathrm{MgCl}_{2}$ Primer- F and $\mathrm{R}$, etc. except the component against which the optimization strategy was intended. In each reaction, the volume of PCR buffer was used one tenth of the total reaction volume which was $25 \mu$ l. For PCR amplification of the GUS gene, DNA was denatured at $94^{\circ} \mathrm{C}$ for $5 \mathrm{~min}$ and then amplified in 30 cycles using $94^{\circ} \mathrm{C}$ for $1 \mathrm{~min}, 65^{\circ} \mathrm{C}$ for $1 \mathrm{~min}$ (annealing) and $72^{\circ} \mathrm{C}$ for $1 \mathrm{~min}$ followed by $5 \mathrm{~min}$ at $72^{\circ} \mathrm{C}$. For $n p t I I$ gene the cycling conditions were $5 \mathrm{~min}$ at $94^{\circ} \mathrm{C}$ denaturtion and 30 amplification cycles using $94^{\circ} \mathrm{C}$ for $1 \mathrm{~min}$, $55^{\circ} \mathrm{C}$ for $1 \mathrm{~min}$ (annealing) and $72^{\circ} \mathrm{C}$ for $1 \mathrm{~min}$ followed by $5 \mathrm{~min}$ at $72^{\circ} \mathrm{C}$. The amplified DNA was run on $0.80 \%$ agarose gel and stained with ethidium bromide $(0.05 \mu \mathrm{l} / \mathrm{ml})$.

\section{Results and Discussion}

The explants of nodal and internodal segments used in this study were obtained from the shoots developed through the in vitro culture of potato sprouts. Therefore, potato sprouts from all the varieties were used as primary explants. 
The surface sterilized sprouts were cultured on MS supplemented with $4.0 \mathrm{mg} / 1$ $\mathrm{BAP}$ and $1.0 \mathrm{mg} / 1 \mathrm{IAA}$. In all the three varieties, optimum responses towards development of shoots from these sprouts was achieved when the sprouts were surface sterilized for $7-8 \mathrm{~min}$ with $0.1 \% \mathrm{HgCl}_{2}$. The developing shoots from such sprouts is presented Fig. 1.

Agar solidified MS supplemented with various concentrations of BAP, Kn, IAA and GA3 were used for the induction of multiple shoots from nodal and internodal segments of all the three potato varieties. Among the two cytokinins (BAP and $\mathrm{Kn}$ ) used in the present study BAP was found to induce the best response towards the development of multiple shoots per explants. Best response towards shoot induction was obtained when both the explants from Diamant were cultured on MS supplemented with $2.0 \mathrm{mg} / 1 \mathrm{BAP}$ and $1.0 \mathrm{mg} / 1 \mathrm{Kn}$. In case of Cardinal, MS supplemented with $2.5 \mathrm{mg} / 1 \mathrm{BAP}$ and $1.0 \mathrm{mg} / 1 \mathrm{Kn}$ can induce considerable number of shoots. The explants from Granola also responded best when cultured on MS supplemented with $2.5 \mathrm{mg} / 1 \mathrm{BAP}$ and $1.0 \mathrm{mg} / 1 \mathrm{Kn}$.

A number of combinations of BAP and IAA were also used for direct regeneration of multiple shoots from node and internodal explants. These combinations of BAP and IAA responded better than the combination of BAP and $\mathrm{Kn}$ in inducing shoots. In Diamant about 10 - 12 shoots regenerated when the explants were cultured on MS supplemented with $4.0 \mathrm{mg} / 1 \mathrm{BAP}$ and $1.0 \mathrm{mg} / 1$ IAA (Fig. 2).

In case of Cardinal maximum shoots were obtained on MS supplemented with $1.5 \mathrm{mg} / 1 \mathrm{BAP}$ and $0.5 \mathrm{mg} / 1$ IAA. But for multiple shoot induction in Granola comparatively high concentration of BAP was required. Granola responded best on MS supplemented with $5.0 \mathrm{mg} / 1 \mathrm{BAP}$ and $1.0 \mathrm{mg} / 1 \mathrm{IAA}$. The results are presented in the Table 1 . These variable responses towards in vitro shoot development were also reported by some previous workers (Hussey and Stacey 1981, Miller et al. 1985, Islam 1990, Mila 1991, Hossain 1994, Bajaj 1981, Khan and Rabbani 1999, Sarker and Mustafa 2002 and Sultana 2005).

In the present investigation, node and internodal segments were also used to regenerate plants through callus culture. Here, BAP and NAA supplemented medium has been found to be effective for callus formation. High callus formation frequency was achieved in Granola (80.0\%) following the use of MS containing $4.0 \mathrm{mg} / 1 \mathrm{BAP}+1.0 \mathrm{mg} / 1 \mathrm{NAA}$. Similar frequency of callus induction was obtained in Diamant in the same media. In case of Cardinal, best callus was obtained in MS containing $3.0 \mathrm{mg} / \mathrm{l}$ BAP $+1.0 \mathrm{mg} / 1$ NAA. Different concentrations of BAP and IAA were employed on MS for shoot development from callus tissue. Shoot buds were found to initiate from those green friable callus within one month (Fig. 3). 
Table 1. Effects of various combinations of BAP and IAA on regeneration and proliferation of multiple shoots from nodal and internodal segments of potato (var. Diamant, Cardinal and Granola).

\begin{tabular}{|c|c|c|c|c|c|c|c|c|c|c|}
\hline \multirow[t]{2}{*}{ Explants } & \multirow[t]{2}{*}{$\begin{array}{c}\mathrm{BAP}+ \\
\mathrm{IAA} \\
(\mathrm{mg} / \mathrm{l})\end{array}$} & \multicolumn{3}{|c|}{$\begin{array}{l}\text { Number of } \\
\text { explants } \\
\text { inoculated }\end{array}$} & \multicolumn{3}{|c|}{$\begin{array}{c}\text { Mean No. of shoot } \\
\text { buds/explant } \\
\text { after } 30 \text { days of } \\
\text { inoculation } \\
\end{array}$} & \multicolumn{3}{|c|}{$\begin{array}{l}\text { Mean number of } \\
\text { shoot buds/explant } \\
\text { after } 60 \text { days of } \\
\text { inoculation }\end{array}$} \\
\hline & & $\mathrm{D}$ & $\mathrm{C}$ & $\mathrm{G}$ & $\mathrm{D}$ & $\mathrm{C}$ & G & $\mathrm{D}$ & $\mathrm{C}$ & $\mathrm{G}$ \\
\hline \multirow[t]{6}{*}{ Node } & $1.0+0.5$ & 25 & 25 & 30 & 6.1 & 6.1 & 4.1 & 10.5 & 15.8 & 10.1 \\
\hline & $1.5+0.5$ & 25 & 25 & 30 & 5.3 & 7.5 & 4.4 & 12.7 & 18.5 & 10.8 \\
\hline & $2.0+1.0$ & 25 & 25 & 30 & 7.4 & 7.1 & 5.0 & 12.4 & 12.0 & 13.1 \\
\hline & $3.0+1.0$ & 25 & 25 & 30 & 8.0 & 7.0 & 5.8 & 15.1 & 12.0 & 14.8 \\
\hline & $4.0+0.5$ & 25 & 25 & 30 & 10.5 & 6.8 & 6.1 & 20.0 & 10.6 & 16.2 \\
\hline & $4.0+1.0$ & 25 & 25 & 30 & 12.0 & 6.6 & 6.6 & 30.5 & 11.1 & 18.5 \\
\hline \multirow[t]{6}{*}{ Internode } & $1.0+0.5$ & 25 & 25 & 30 & 4.3 & 4.5 & 4.0 & 5.2 & 12.2 & 10.2 \\
\hline & $1.5+0.5$ & 25 & 25 & 30 & 4.6 & 6.8 & 4.2 & 6.0 & 15.7 & 11.1 \\
\hline & $2.0+1.0$ & 25 & 25 & 30 & 5.5 & 6.2 & 4.9 & 6.7 & 17.1 & 13.2 \\
\hline & $3.0+1.0$ & 25 & 25 & 30 & 6 & 5.5 & 5.6 & 8.8 & 13.1 & 14.1 \\
\hline & $4.0+0.5$ & 25 & 25 & 30 & 6.1 & 5.4 & 5.9 & 11.1 & 10.3 & 17.1 \\
\hline & $4.0+1.0$ & 25 & 25 & 30 & 10.5 & 5.1 & 6.3 & 12.0 & 10.2 & 17.2 \\
\hline
\end{tabular}

$\mathrm{D}=$ Diamant, $\mathrm{C}=$ Cardinal, $\mathrm{G}=$ Granola.

Apart from these regeneration experiments spontaneous microtuberization (Fig. 4) was obtained from these proliferated shoots when they were subcultured on MS containing $4.0 \mathrm{mg} / 1 \mathrm{BAP}+1.0 \mathrm{mg} / 1$ IAA. These spontaneous microtuberization was found to initiate within six - seven week of culture. Further culturing of these green in vitro grown microtubers was found to regenerate a large number of shoots which were almost identical in size and shape (Fig. 5). These microtuber formation and the proliferation of shoots from these microtubers was carried in case of Diament and Cardinal.

Half strength of MS without hormonal supplement was sufficient in initiating and developing healthy roots. Among IAA, IBA and NAA used for root induction, MS containing $0.2 \mathrm{mg} / 1 \mathrm{IBA}$ showed best response in developing roots (Fig. 6). However, in some indigenous potato varieties best response in root induction was obtained in MS supplemented with $0.1 \mathrm{mg} / 1$ IAA (Sarker and Mustafa 2002).

Transformation experiments for the three potato varieties (Diamant, Cardinal and Granola) were conducted by using nodal and internodal segments as explants. Transformation ability of various explants was detected using GUS histochemical assay (Fig. 7). In all the varieties nodes were found to show the best transformation ability, followed by internodal segments. Results of these observations are presented in Table 2. In the present investigation transformation efficiency of explants in all the varieties was found to be maximum with bacterial 
suspension having on optical density of about 1.0 at $600 \mathrm{~nm}$. An incubation period of 60 minutes followed by $72 \mathrm{hr}$ of cocultivation was maintained towards effective transformation.
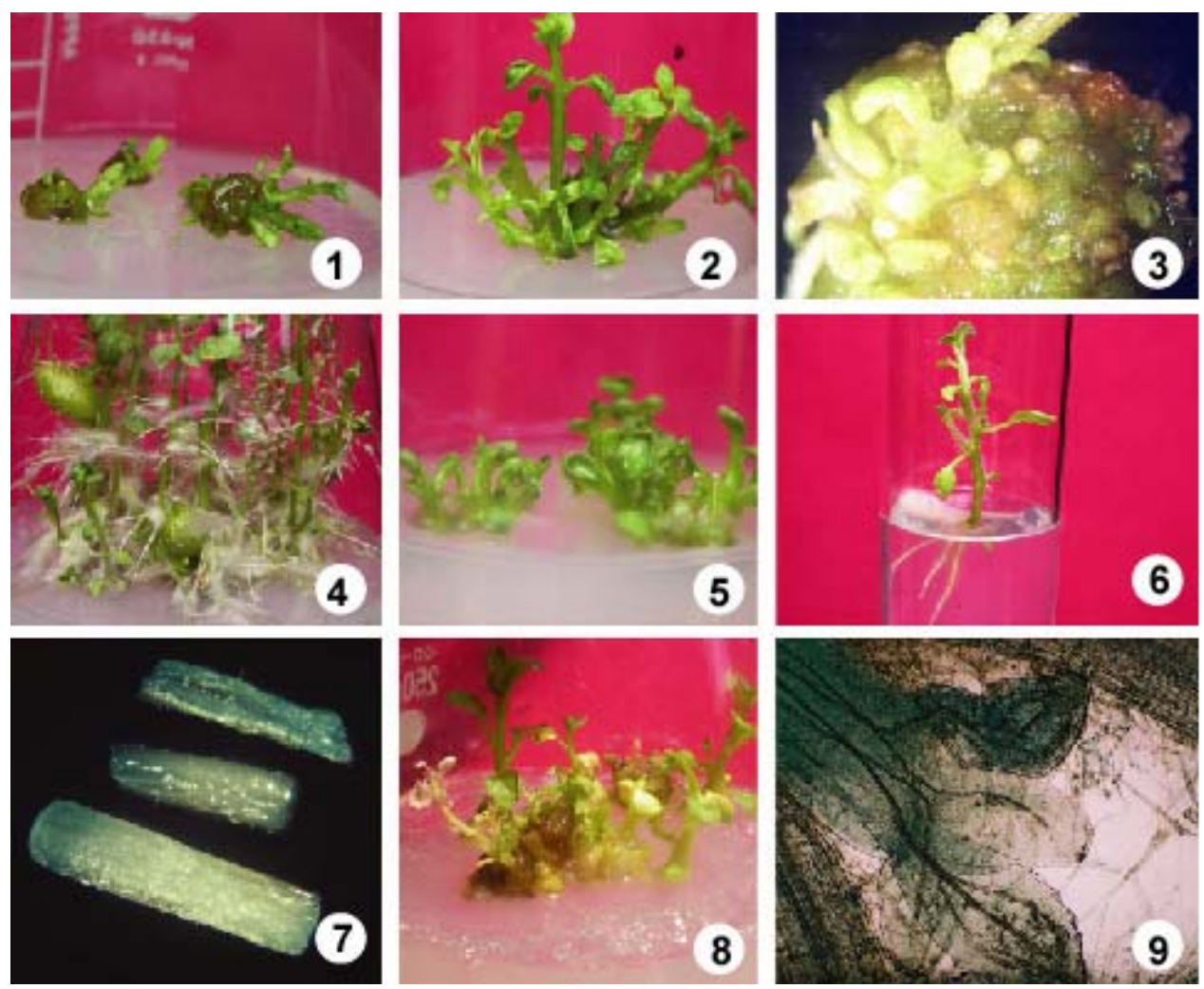

Figs 1-9: Plant regeneration and genetic transformation in potato. 1. Development of shoots from sprouts on MS supplemented with $4.0 \mathrm{mg} / 1 \mathrm{BAP}$ and $1.0 \mathrm{mg} / 1$ IAA in Diamant. 2. Multiple shoots regenerated from nodal segment in Diamant on MS supplemented with $4.0 \mathrm{mg} / 1 \mathrm{BAP}+1 \mathrm{mg} / \mathrm{l}$ IAA. 3. Shoot buds developing from the callus in Diamant on MS with $1.5 \mathrm{mg} / \mathrm{l} \mathrm{BAP}$ and $1.0 \mathrm{mg} / \mathrm{l}$ IAA. 4. Spontaneous microtuberization in nine week culture of Diamant in $4.0 \mathrm{mg} / \mathrm{l} \mathrm{BAP}$ and 1.0 mg/l IAA. 5. In vitro shoots regenerated from microtubers of Diamant. 6. Rooting on MS with 0.2 $\mathrm{mg} / \mathrm{l} \mathrm{IBA}$. 7. Stereomicroscopic view of histochemical localization of GUS activity (blue coloured zones) at the entire cut surface internodal segments $(\times 27)$. 8. Selection of transformed shoots of Diamant in presence of $150 \mathrm{mg} / \mathrm{l} \mathrm{kanamycin} \mathrm{(note} \mathrm{that} \mathrm{the} \mathrm{non} \mathrm{transformed} \mathrm{shoots} \mathrm{became} \mathrm{albino).}$ 9. Magnified view of GUS positive cells within the internal tissues of the shoot primodia developed from the internodal explant $(\times 10)$.

In a separate set of experiments Sarker et al. (2009) reported that an incubation period of $40 \mathrm{~min}$ was optimum in case of variety Cardinal and Atlas. Lecardonnel et al. (1999) also used $40 \mathrm{~min}$ for infection and coculture was maintained for three days in potato. Influence of regulatory factors on the transformation efficiency of various explants was also observed by Islam (1998) in peanut and by Mansur et al. (1993) in peanut. 
Selection of the transformants was carried out using various concentrations of kanamycin. However, the presence of kanamycin greatly hampers growth of the explants and as a result many putative transformants may have been lost. For this reason immediately after cocultivation kanamycin was not applied for selection, rather regeneration was encouraged from the cocultivated explants. Well developed shoots were obtained from infected nodal and internodal segment after 15 - 18 days of culture and well developed calluses were obtained from infected explants following three days of culture.

Table 2. Responses of various explants of potato towards genetic transformation with Agrobacterium strain LBA4404 containing the binary plasmid pBI121 analyzed by transient GUS histochemical assay.

\begin{tabular}{llcccc}
\hline Variety & Explant & $\begin{array}{c}\text { No. of } \\
\text { explants } \\
\text { infected }\end{array}$ & $\begin{array}{c}\text { No. of explants } \\
\text { assayed for GUS } \\
\text { expression }\end{array}$ & $\begin{array}{c}\text { No. of explants } \\
\text { assayed +ve } \\
\text { for GUS }\end{array}$ & $\begin{array}{c}\text { \% of GUS } \\
\text { positive } \\
\text { explant }\end{array}$ \\
\hline Diamant & Node & 500 & 50 & 46 & 92 \\
& Internode & 500 & 50 & 42 & 84 \\
Cardinal & Node & 500 & 50 & 43 & 86 \\
& Internode & 500 & 50 & 41 & 81 \\
& Node & 500 & 50 & 44 & 88 \\
& Internode & 500 & 50 & 45 & 90 \\
\hline
\end{tabular}

In the present investigation higher concentrations of kanamycin were applied to screen the transformed shoots effectively. For this purpose kanamycin concentration was gradually increased from 50 to $200 \mathrm{mg} / \mathrm{l}$. It was found that all the control shoots failed to survive at $150 \mathrm{mg} / \mathrm{l}$ kanamycin within 15 days. Therefore, the shoots that survived in the medium containing $150 \mathrm{mg} / \mathrm{l}$ kanamycin were considered as transformed (Fig. 8). All the shoots obtained though selection were subjected to rooting in a medium with $50 \mathrm{mg} / 1 \mathrm{kanamycin}$ where the roots were found to develop properly. Here, it may be pointed out that the selection procedure developed during this study has been found to be effective in recovering transformed plantlets. Stable expression of GUS gene was visualized through histochemical staining in the regenerating shoots from nodes developed in presence of selection pressure of $150 \mathrm{mg} / \mathrm{l} \mathrm{kanamycin} \mathrm{(Fig.} \mathrm{9).} \mathrm{These}$ tests were carried out regularly for more than three months and the results of these experiments are presented in Table 3. The regenerated roots from the transformed shoots also showed GUS expression . 
Table 3. Stable GUS expressions in the putative transformed plantlets following three months of selection in presence of higher concentration of kanamycin (150 - 200 $\mathrm{mg} / \mathbf{1})$.

\begin{tabular}{lccc}
\hline $\begin{array}{l}\text { Plant parts } \\
\text { tested }\end{array}$ & $\begin{array}{c}\text { Total No. of parts } \\
\text { tested }\end{array}$ & $\begin{array}{c}\text { No. of GUS positive } \\
\text { parts }\end{array}$ & $\begin{array}{c}\text { Percentage of GUS } \\
\text { positive parts }\end{array}$ \\
\hline Leaf & 20 & 8 & 40 \\
shoot & 20 & 5 & 25 \\
\hline
\end{tabular}

The transgenic nature of the shoots was confirmed by PCR amplification of the GUS and nptII gene present within the genomic DNA (Figs 10 and 11) of six randomly selected transformants. Specific primers were used for this purpose as detailed in the Materials and Methods section. Amplified DNA was analyzed through agarose gel electrophoresis. From the gel it was observed that the single band formed in each of the six transformed plantlets were identical to the amplified DNA of transformed tobacco marker. This result indicated that both the GUS and nptII genes were inserted in the genomic DNA of six transformed plantlets.
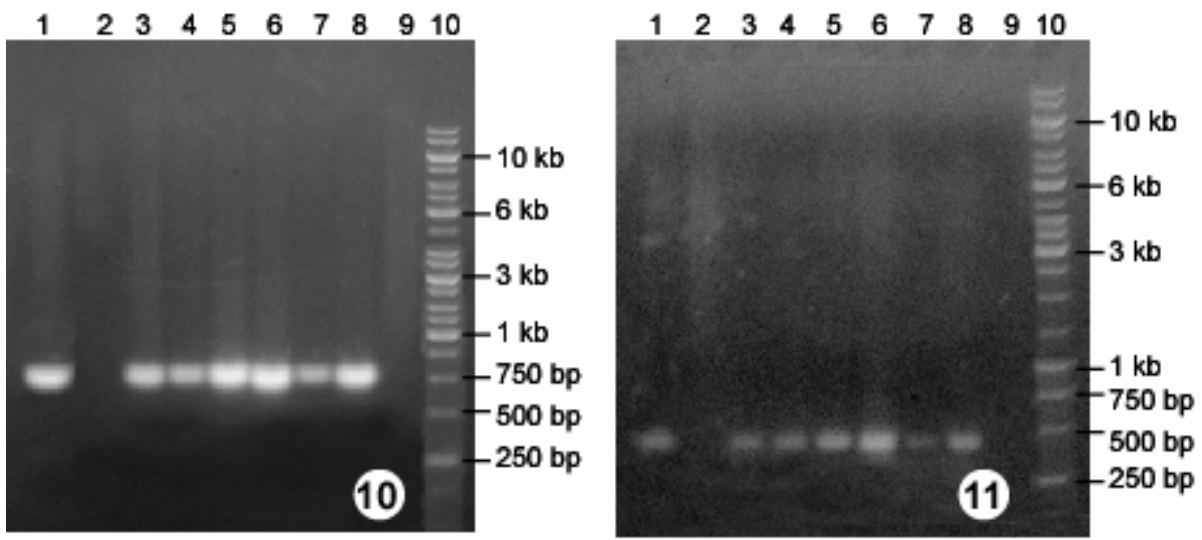

Figs 10-11: 10. PCR amplification of GUS gene from transformed plants. Lane-1. Genomic DNA of transformed tobacco plant. Lane-2. Genomic DNA of non-transformed potato plant. Lane-3-8. Amplified DNA of transformed potato plants. Lane-9. Water control. Lane-10. Ladder. 11. Same as 10 but with nptII gene.

The protocol of Agrobacterium-mediated genetic transformation developed through the present investigation can be used for the production of transgenic potato plants for specific purpose. In this case the protocol was primarily developed using screenable marker gene like GUS and selectable marker gene like nptII. Using this protocol, in future agronomically important gene/s can be transferred to the potato varieties grown in Bangladesh. Particularly for the development of fungal disease resistant potato variety this technique of transformation can be exploited. 


\section{Acknowledgements}

Authors are grateful to Professor A.S. Islam and Professor M.M. Haque for their suggestions during the preparation of this manuscript and critically going through it. The authors are also thankful to BARI authorities for providing the potato tubers for this investigation.

\section{References}

Bajaj YPS (1981) Regeneration of plants from potato meristems freeze preserved for 24 months. Euphytica 30(1): 141-145.

BBS (2009) Bangladesh Bureau of Statistics, Agriculture Wing. Ministry of Planning, People's republic of Bangladesh.

Doyle JJ and Doyle JL (1990) Isolation of Plant DNA from fresh tissue Focus 12: 13-15.

Herrera-Estrella L, Depicker A, Van Montague M and Schell J (1983) Expression of chimeric genes transferred into plant cells using a Ti-plasmid derived vector. Nature 303: 209.

Hossain MJ (1994) In vitro propagation of potato (Solanum tuberosum L.). Plant Tissue Cult. 4(1): 33-37.

Hussey G and Stacey NJ (1981). In vitro propagation of potato (Solanum tuberosum L.) Ann. Bot. 48: 787-796.

Islam A (1990) Studies of in vitro microtuber formation in potato (Solanum tuberosum L.). M. Sc. thesis, Plant Breeding and Tissue Culture Lab., Department of Botany, University of Dhaka.

Islam A (1998) In vitro regeneration and genetic transformation of peanut (Arachis hypogaea L.). M. Sc. thesis, Plant Breeding and Tissue Culture Lab.,' Department of Botany, University of Dhaka.

Jefferson RA, Kavanagh TA and Bevan MW (1987) GUS Fusion: $\beta$-glucuronidase as a sensitive and versatile gene fusion marker in higher plants. EMBO J. $6:$ 3901-3907.

Joung H, Jeon J H, Park S W and Kim S (1993) Potential impact of mass produced potato microtubers on conventional potato agriculture. Paper presented in Int. Plant Tissue Culture Conference, held from 19-21 Dec. 1993 at Botany Department of Dhaka University.

Khan SAKU and Rabbani MG (1999). Effect of preincubation of tubers on in vitro culture of three potato varieties. Plant Tissue Cult. 9(1): 1-9.

Lecardonnel A, Prevost G, Beaujean A, Sangwang RS and Norrell BSS (1999) Genetic transformation of potato with nptII-GUS marker gene enhances foliage consumption by Colorado potato beetle larvae. Molecular Breed. 5: 441-451.

Mansur EA, Lacorte C, Defriitus VG, Deoliviera DF, Timmerman B and Cordeiro AR (1993) Regulation of transformation efficiency of peanut (Arachis hypogaea L.) explant by Agrobacterium tumefaciens. Plant Sci. 89: 93-99.

Mila NB (1991) Optimization of in vitro microtuber formation in potato (Solanum tuberosum L.). M. Sc. thesis, Plant Breeding and Tissue Culture Lab., Department of Botany, University of Dhaka. 
Miller PR, Amirouche L, Stuchbury T and Mathews S (1985) The use of plant growth regulators in micropropagation of slow-growing potato cultivars. Potato Research. 28: 479-486.

Sarker RH and Mustafa BM (2002) Regeneration and Agrobacterium-mediaied genetic transformation of two indigenous potato varieties of Bangladesh. Plant Tissue Cult. 12(1): 69-77.

Sarker RH, Mustafa BM, Biswas A, Mahbub S, Nahar M, Hashem R and Hoque MI (2003) Agrobacterium-mediate transformation of lentil (Lens culinaris Medik.) Plant Tissue Cult. 13(1): 1-12.

Sarker SR, Hossain M and Shirin F (2009) Precise Incubation Period for the Agrobacterium-mediate transformation efficiency in potato (Solanim tuberosum) cvs. Cardinal and Atlas. Plant Tissue Cult. \& Biotech. 19(2): 227-235.

Sultana P (2005) In vitro regeneration and Agrobacterium- mediate genetic transformation of potato (Solanum tuberosum L.), M. S. thesis, Plant breeding and Biotechnology lab., Department of Botany, University of Dhaka.

Trujillo C, Rodriguez-Arango, Jaramillo S, Hoyos R, Orduz S and Arango R (2001) Onestep transformation of two Andean potato cultivers (Solanum tuberosum L.) subsp. andigend). Plant Cell Reports 20: 637-641.

Voyda ME and Belknap WR (1992) The emergence of transgenic potato as commercial products and tools for basic research. Transgenic Res. 1: 149-163. 